\title{
Correction to: Immigration Attitudes and Subjective Well-Being: A Matter of Identity?
}

\author{
Heinz Welsch ${ }^{1}$ D $\cdot$ Philipp Bierman ${ }^{2} \cdot$ Jan Kühling ${ }^{1}$ \\ Published online: 27 August 2021 \\ (c) The Author(s) 2021
}

\section{Correction to: Journal of Happiness Studies (2021) 22:1563-1581 https://doi.org/10.1007/s10902-020-00284-y}

The article "Immigration Attitudes and Subjective Well-Being: A Matter of Identity?", written by Heinz Welsch, Philipp Bierman, Jan Kühling, was originally published Online First without Open Access. After publication in volume 22, issue 4, page 1563-1581 the author decided to opt for Open Choice and to make the article an Open Access publication. Therefore, the copyright of the article has been changed to (C) The Author(s) 2020 and the article is forthwith distributed under the terms of the Creative Commons Attribution 4.0 International License, which permits use, sharing, adaptation, distribution and reproduction in any medium or format, as long as you give appropriate credit to the original author(s) and the source, provide a link to the Creative Commons licence, and indicate if changes were made. The images or other third party material in this article are included in the article's Creative Commons licence, unless indicated otherwise in a credit line to the material. If material is not included in the article's Creative Commons licence and your intended use is not permitted by statutory regulation or exceeds the permitted use, you will need to obtain permission directly from the copyright holder. To view a copy of this licence, visit http://creativecommons.org/licenses/by/4.0. Open Access funding enabled and organized by Projekt DEAL.

The original article has been corrected.

Publisher's Note Springer Nature remains neutral with regard to jurisdictional claims in published maps and institutional affiliations.

The original article can be found online at https://doi.org/10.1007/s10902-020-00284-y.

Heinz Welsch

welsch@uni-oldenburg.de

1 Department of Economics, University of Oldenburg, 26111 Oldenburg, Germany

2 Department of Sociology, University of Magdeburg, 39104 Magdeburg, Germany 